CONFERÊNCIAS 


\section{LIMITES E POSSIBILIDADES DA EDUCAÇÃO BILÍNGÜE INTERCULTURAL NO PERU}

Rodrigo Montoya Rojas*

A

educação bilínguie intercultural nos países andinos da América do Sul é um meio para que os povos indígenas - dos Andes, da Amazônia e também da Costa - possam afirmar o valor de suas culturas e suas línguas e, em última instância, para continuar a existir. Em face da educação oficial em espanhol, que não leva em conta a diversidade cultural e lingüística dos países andinos, a educação bilíngüe intercultural é uma alternativa de uma potencialidade extraordinária. Infelizmente, o contexto adverso decorrente do processo de dominação cultural e lingüística não permite utilizar toda essa potencialidade. Os projetos independentes da "Educação Bilíngüe Intercultural" (EBI) - religiosos ou não - recebem no Peru um apoio mais declarado do que real, enquanto o projeto governamental na Bolívia é contestado abertamente pelos sindicatos de professores $\mathrm{e}$ - sob uma forma dissimulada - por uma parte importante dos próprios funcionários. A educação bilíngüe intercultural tem também outros problemas como a precária e má preparação dos professores, suas condições de vida e de trabalho tão difíceis quanto a extrema pobreza dos estudantes indígenas. Apesar de tudo, alguns milhares de professores, e de professores e professoras primários ${ }^{1}$, trabalham nessas condições certamente

* Universidad Nacional Mayor de San Marcos, Lima-Peru.

1 Nota do tradutor: $O$ autor do texto refere-se na maioria dos casos a "instituteurs" $e$ "institutrices" que nāo têm correspondente em português. Optei por "professores" e "professoras", simplesmente. Contudo, quero ressaltar que se trata de professores das séries iniciais. 
MONTOYA ROJAS, R. Limites e possibilidades da educação...

difíceis e hostis. Se o espanhol enquanto língua dominante é capaz de se introduzir nas línguas indígenas como o quetchua, as dificuldades para a educação bilíngüe intercultural se multiplicam.

Nesta conferência, exporei alguns problemas importantes da educação bilíngüe intercultural no Peru (EBI), muito particularmente aqueles do ensino do quetchua e do espanhol, da política contraditória do Estado e das condições de existência e de trabalho das professoras e professores bilíngües no Peru. No meu livro "Por una educación bilingue en el Peru: reflexiones sobre cultura y socialismo" ( Montoya, 1990) apresentei uma série de resultados positivos e uma proposta em 20 pontos para tentar estender a EBI para todo o país. $\mathrm{Na}$ mesma época começaram os trabalhos do Projeto de Educação Bilíngüe em Iquitos - a cidade mais importante da Amazônia peruana - graças a um acordo entre o Aidesep (Associação Inter-Étnica para o Desenvolvimento da Amazônia Peruana) e o Instituto Superior Pedagógico de Iquitos, com o apoio econômico da Comunidade Européia, para formar novos professores bilíngües. $\mathrm{Na}$ mesma época, também chegava ao seu fim o financiamento alemão do Projeto de Puno e, de outra parte, as escolas bilínguies de Ayacucho e das Ashaninkas da Amazônia Central continuaram a ser fechadas em consequiência da violência política do Sendero Luminoso e a resposta, igualmente violenta, das Forças Armadas Peruanas.

Hoje, em 1999/2000, resta ainda o Pebian (Projeto de Educação Bilíngüe Intercultural no rio Alto Napo, um afluente do Amazonas), continuam os trabalhos do projeto em Iquitos bem como o apoio limitado do Estado às escolas bilíngües em Puno e em outras regiões do país. O Mestrado em Lingüística Andina e Educação na Universidade de Puno continua, apesar de suas dificuldades; recebe apoio do Proeibandes (Projeto de Educação Bilíngüe Intercultural em Cochabamba, Bolívia) sustentado pela ajuda financeira da Cooperação Técnica Alemã (GTZ).

Poderia ser útil enumerar aqui um certo número de experiências e de problemas, tratados no meu livro de 1990 , bem como as propostas para generalizar a educação bilíngüe no Peru. Os resultados positivos mais importantes são os seguintes: a valorização dos grupos étnicos e a afirmação da identidade étnica dos povos indígenas; a confiança e melhores condições psicológicas para que as crianças aprendam; uma produção significativa de textos pedagógicos; uma contribuição etnográfica para conhecer melhor os grupos étnicos; um passo à frente para aprender o espanhol mais facilmente. Os principais problemas são: o contexto pouco favorável; a dominação colonial da cultura peruana; a hipocrisia estrutural dos Estados e dos governos; a oposição das classes e dos grupos dominantes regionais e locais; a interiorização da domi- 
MONTOYA ROJAS, R. Limites e possibilidades da educação...

nação pelos próprios indígenas, a falta de meios de comunicação; a escola como uma forma de sedentarização, como vanguarda do capitalismo no interior amazônico e como substituto da educação indígena; as difíceis condições de existência e de trabalho das professoras e professores, sua imagem desvalorizada; a extrema pobreza dos alunos; e, finalmente, as dificuldades teóricas e práticas dos diversos projetos privados de educação bilíngüe.

As 20 propostas eram: a necessidade urgente de uma política de educação bilíngüe do Estado; eliminar o sistema único de educação escolar num país multicultural e plurilíngüe como o Peru; estender a educação bilíngüe a todas as escolas de grupos étnicos; adaptar a educação escolar às exigências de equilíbrio ecológico da Amazônia; formar professoras e professores bilíngües em todos os Institutos Pedagógicos Superiores; recrutar somente professoras e professores com uma clara vocação para o ensino; desenvolver uma educação para a socialização do poder político e contra a verticalidade e o autoritarismo; questionar e transpor a aparente oposição entre a ciência e o saber popular; uma educação bilíngüe não tem sentido se for utilizada apenas como um instrumento para traduzir a cultura ocidental; introduzir a prática da experimentação como um meio adequado de conduzir ao conhecimento; dizer não à escola como uma prisão do conhecimento; educar através do trabalho; dar atenção especial à formação afetiva e artística; promover o esporte amador; fazer oposição frontal ao centralismo de Lima e à burocratização do Ministério da Educação; recusar a ideologia do assistencialismo; ${ }^{2}$ promover a pesquisa permanente sobre a realidade linguiística, pedagógica e antropológica; a necessidade de formar tradutores; e, finalmente, o ensino de línguas indígenas como segunda língua.

Duas novidades importantes para a educação bilíngüe apareceram nos anos 90: uma decisão oficial do governo boliviano de Sanchez de Losada para introduzir a EBI em todo sistema educacional e a criação de um mestrado de educação bilínguie intercultural na Universidade San Simon de Cochabamba, também na Bolívia, como centro acadêmico permanente de formação de professoras e professores bilíngües para a região sul-americana. ${ }^{3}$

2 A ideologia de assistencialismo e a necessidade criada entre os pobres de pedir presentes, mais do que de exigir seus direitos, é uma conseqüência do paternalismo e do assistencialismo do Estado bem como da maior parte das organizações não-governamentais (ONGs).

3 Até hoje os projetos privados não-religiosos de educação bilíngüe duravam somente o tempo que durava o financiamento dos organismos intemacionais. Em Cochabamba, a Cooperação Alemã GTZ, terminará seu compromisso financeiro e a Universidade de San Simon continuará o projeto. A experiência adquirida em Puno foi extremamente rica para a equipe dirigida por Luis Enrique Lopez. 
MONTOYA ROJAS, R. Limites e possibilidades da educação...

Nesses últimos anos, eu segui bem de perto o trajeto da EBI. Participei também como professor no curso de formação de professoras e professores para o quadro da reforma educacional boliviana, nos Mestrados da Universidade de Puno e da Universidade de Cochabamba. ${ }^{4}$

\section{Para retornar ao primeiro passo}

A educação bilíngüe começou na América Latina graças principalmente à iniciativa de William Cameron Townsend, um pastor protestante norte-americano que durante sua juventude foi um vendedor de bíblias em espanhol entre os índios quichés na Guatemala que falavam apenas a sua própria língua. Ele estava persuadido de que tinha entendido um apelo de Deus para conduzir ao Seu caminho os índios do mundo inteiro. Criou, então, uma grande organização de duas faces: de um lado, os Tradutores Wicliffe da Bíblia como instituição religiosa e, de outro, o Instituto Lingüístico de Verão, como um centro de pesquisa lingüística e de aplicação pedagógica. Se os católicos espanhóis e portugueses após 1492 apenas batizaram os indígenas americanos para torná-los cristãos, os novos pregadores protestantes do século $\mathrm{XX}$ atingirão esse mesmo propósito traduzindo "a palavra de Deus" em todas as línguas indígenas, ensinando o modo de vida ocidental e lutando contra as suas bruxarias e seus demônios.

Em 1946, foi criada através da iniciativa privada, a primeira escola na Amazônia peruana, religiosa na essência e pedagógica na forma. O Ministério da Educação Peruano da época autorizou esse projeto. Hoje, 53 anos depois, os tradutores da Bíblia e o Instituto Lingüístico de Verão continuam no Peru e em uma centena de países do mundo. ${ }^{5}$ Entre 1946 e 1987, a Bíblia já estava traduzida em 17 línguas indígenas do Peru e o trabalho das duplas de pastores e de lingüistas continua. ${ }^{6}$

4 A informação para esta conferência é resultado de meu contato estreito com esses professores. Em julho de 1998, meus alunos do Mestrado em Puno executaram diversos trabalhos segundo suas preferências. Os de Vicentina Huamanquispe, Carmen Rosa Flores e David Peter Calsin são mencionados aqui e em muitas outras retomadas. Eu agradeço-lhes pela qualidade e frescor de seus textos. Em condições bastante adversas e hostis, eles fizeram um trabalho admirável.

5 O Instituto Lingüístico de Verão foi expulso do Equador em 1985. No Peru, um coro de oposição não conseguiu o mesmo efeito em 1970. O governo do General Velasco Alvarado preferiu dar-lhe o seu apoio.

6 Para uma melhor informação sobre os Tradutores da Bíblia ver Wikliffe Bible Translators, 1963 e os textos do Instituto Lingüístico de Verão de 1987, 1986, 1979. 
MONTOYA ROJAS, R. Limites e possibilidades da educação...

Nas escolas bilíngües do Instituto Lingüístico de Verão ensina-se a ler e a escrever as línguas indígenas e também o espanhol como segunda língua. A língua indígena é usada como um instrumento para traduzir mensagens religiosas e as virtudes da cultura ocidental. Como no século XVI, os pastores tradutores da Bíblia estão convencidos de que seu Deus é "único e verdadeiro", que os Deuses indígenas são falsos e que a vida entre os índios seria dirigida pelos demônios. Eliminar esses demônios é um dos objetivos da educação bilíngüe religiosa e protestante.

Muito antes de William Cameron Townsend, a idéia subversiva de educar as crianças aymaras e quetchuas dos Andes peruanos nas suas próprias línguas foi proposta pelo professor Manuel Z. Camacho, em 1904, quando ele criou uma escola em Plateria, uma aldeia aymara, perto de Puno. ${ }^{7}$ Mais tarde, nos anos 20, o professor universitário José Antonio Encinas propôs que a nova escola deveria levar em conta as diferenças culturais dos povos. Entre $1949 \mathrm{e}$ 1951 a professora Maria Asuncion Galindo realizou uma primeira experiência de educação bilíngüe com as crianças de Puno. Nenhuma dessas propostas contou com o apoio oficial porque as autoridades educacionais estavam interessadas apenas em difundir o espanhol como a língua única do Estado.

A primeira geração dos dirigentes indígenas da Amazônia peruana formada quase que exclusivamente por homens, que hoje já têm 40 anos, aprendeu a ler e a escrever nas escolas bilíngües do Instituto Lingüístico de Verão e também em algumas escolas católicas dos Salesianos e dos Jesuítas. Eles foram os primeiros a descobrir que a educação bilíngüe religiosa se utilizava de suas línguas e não levava em consideração suas culturas; que os professores enviados pelo Ministério da Educação não conheciam nem as línguas indígenas nem suas culturas; e, que estes abusavam, de fato, de suas filhas. Tais dirigentes foram também os primeiros a questionar a educação que suas crianças recebiam. Dessas evidências nasceu um caminho para a futura educação bilíngüe intercultural que poderia ser definido como uma forma de defesa das identidades culturais dos povos indígenas da Amazônia. Esse segundo caminho é o resultado da pesquisa linguística, de sua proposta de distinguir a língua indígena (L1) do espanhol como segunda língua (L2), de reconhecer o plurilingüismo e a diglossia como fenômeno de dominação de uma língua oficial sobre as demais. $O$ terceiro e último caminho é o percurso antropológi-

7 Naquela época os grandes proprietários de terras não queriam que "seus indios" aprendessem a ler e a escrever. Numerosos professores pagaram com suas vidas o engajamento de ensinar clandestinamente às crianças indígenas. No meu romance El tiempo del descanso (Montoya, 1997) essa história é recriada em um dos capítulos. 
MONTOYA ROJAS, R. Limites e possibilidades da educação...

co que reconhece a diversidade cultural, a dominação de uma cultura sobre as outras e a necessidade de um diálogo de culturas em igualdade de condições.

Depois do Instituto Linguístico de Verão, o segundo projeto de educação bilíngüe no Peru foi proposto pelo Departamento de Linguiística da Universidade de San Marcos, de Lima, que em 1962 começou seus trabalhos na comunidade de Quinua, em Ayacucho, prestando uma atenção particular ao ensino de espanhol como segunda língua, para não incidir no grave erro da educação oficial que confunde a língua materna com o espanhol. Mais tarde, nos anos 70, entre os Quetchuas da Amazônia peruana, começou, com o Projeto de Educação Bilíngüe Intercultural do Rio Alto Napo, Pebian, por iniciativa do padre missionário canadense católico Jean Marc Mercier, uma das experiências mais ricas. Sua proposta de interculturalidade que aparece no livro Nosotros Los Napu runa (Nós os homens do Napo) é muito importante e merece uma atenção maior ( Mercier, 1979 e Montoya, 1990).

O quarto projeto foi proposto pela Cooperação Técnica Alemã em Puno entre 1980 e 1990. O quinto corresponde ao esforço do Centro Amazônico de Antropologia e de Aplicação Prática, CAAAP, uma instituição católica que trabalhou com os Ashaninkas da Amazônia Central até a chegada do Sendero Luminoso. O sexto é o projeto de Iquitos. É necessário registrar, também, as experiências de algumas organizações não-governamentais (ONGs), como a Cadep em Cuzco. Hoje essas ONGs têm uma responsabilidade maior. Voltarei a isso mais à frente.

\section{Problemas lingüísticos e pedagógicos}

Vicentina Huamanquispe fala de uma turma de matemática em quetchua em que observou:

Na escola de Muruhuanca, a língua quetchua foi utilizada como um instrumento para ensinar os conteúdos do espanhol. Eis um exemplo: quando a professora pede à menina Roxana para escrever o número $18 \mathrm{em}$ quetchua, esta permanece olhando $o$ espaço em branco no caderno. Tentando ajudá-la, a professora falou em quetchua dizendo churay unuwan uchuwan que quer dizer, escreva o uno e o ocho, pronunciando esses dois números em espanhol dentro do sistema fonético do quetchua que muda uno em unu e ocho em uchu. Essa transformação altera o 
sentido porque unu em quetchua significa 'água' e uchu 'pimenta'. Literalmente churay unuwan uchuwan quer dizer 'coloque a água com a pimenta'. Para Roxana essas palavras não tinham sentido.( Huamanquispe, 1999, p.13)

Em outro momento na mesma classe a professora pede que os alunos repitam com ela :

"Haqnata kiypi ripasaychis:: huk, iskay, kimsa, tawa, phisqa, suqta .. a ver haqnata repitishkanis hina"( Huamanquispe, 1999, p. 46)

Isso quer dizer literalmente: "Tentem de novo, assim: um, dois, três, quatro, cinco, seis. Vejamos, repitamos assim." Os verbos espanhóis "repetir" e "tentar de novo" são empregados substituindo esses mesmos verbos do quetchua.

David Peter Calsin apresenta uma transcrição de uma turma em quetchua de um professor na Comunidade de Ccollana, província de Azangaro, em Puno, que utiliza os verbos espanhóis "tomar", "falar", "faltar" e "escrever" e as palavras "café da manhã”, “galinha”, "asno", "gato", "leitão", "bosque” e "adeus" como se o quetchua não tivesse esses verbos e essas palavras. Ele repete, além disso, as palavras “já", "muito bem”, “vejamos", “sim”, "nusherto"( No es cierto?, em espanhol) "não é verdade então?" com uma pronúncia quetchua.

O problema de fundo nos textos citados é a prática, infelizmente freqüente, de substituir os verbos e as palavras quetchua por palavras e verbos espanhóis. É o quetchua que perde e o espanhol que ganha. Nós já sabemos que, nos contextos de multiculturalismo e plurilingüismo, os empréstimos lingüísticos são numerosos e que o desejo de conservar a pureza da língua não tem sentido. Adotar a palavra "avião" em quetchua não tem a mesma importância que substituir o verbo quetchua juk kutitawan ruway pelo verbo espanhol "repetir", que quer dizer exatamente a mesma coisa. A questão é porque aqueles que falam o quetchua como língua materna substituem os verbos e palavras quetchuas por seus equivalentes espanhóis? Devemos deixar de lado a possibilidade de que eles não conheçam essas palavras porque eles as conhecem com certeza e se servem delas em diferentes contextos. Uma outra hipótese poderia ser esboçada assim: eles agem dessa forma porque querem mostrar, consciente ou inconscientemente, que eles já possuem um conhecimento do espanhol. A diglossia como um fenômeno de dominação de uma língua de prestígio sobre as outras aparece como um elemento decisivo para explicar a substituição comentada aqui. ${ }^{8}$

8 Quando se traduz a palavra "rádio" - que nāo existe em quetchua - pelas palavras 
Para as pessoas que, num contexto geral de diglossia, falam somente uma língua indígena, esse monolingüismo é considerado como um fator de demérito. Por essa razão, não é difícil compreender os enormes esforços que os indígenas fazem para aprender a língua de prestígio e para mostrar que eles já detêm ao menos certos elementos da cultura dominante. $\mathrm{O}$ bilingüismo é $\mathrm{O}$ resultado parcial desse esforço e não unicamente uma consequiência de uma coexistência linguiística no interior de uma região. Fora do mundo acadêmico, o interesse de conservar uma certa pureza lingüística praticamente não existe. Uma rápida olhada sobre as tendências lingüísticas, contidas nos dados dos recenseamentos após 1940 , mostra que as taxas de monolingüismo caem rapidamente enquanto que o bilingüismo se multiplica de uma maneira acelerada (Montoya, 1990).

As professoras e professores nas escolas bilíngües do país conhecem melhor sua língua indígena do que o espanhol. Entre os pais das crianças acontece o mesmo. Huamanquispe constata: "Os pais não conhecem a escrita (do espanhol) entretanto eles falam e pronunciam (o espanhol) mesmo se não o falam muito bem, e se misturam quetchua e espanhol". (Huamanquispe, 1999 , p. 39)

Por outro lado, Calsin (1999) ressalta:

A escola está localizada a dez quilômetros ao norte de Azangaro; lá, descobrimos que as crianças têm um nível de bilingüismo aditivo; a maioria é bilíngüe desde o berço, entretanto a língua mais usada é o quetchua. Na cidade, quando eles se encontram frente a um desconhecido, falam espanhol. Para superar essa situação deve-se fazer um trabalho consciente na perspectiva social e elevar a auto-estima pessoal da criança.(p. 16)

Se as crianças já são bilíngües do berço, esse fato é muito mais importante do que parece porque o espaço para o monolingüismo é tanto mais reduzido. Num contexto cultural e linguiístico como esse, os professores e professoras não têm a força necessária para ir contra a corrente. O problema é tanto mais sério uma vez que muitos desses professores não têm apenas um conhecimento

wayara wasi, a casa do vento, comete-se certamente um excesso com o propósito explícito de não contaminar a língua com palavras estrangeiras. 
MONTOYA ROJAS, R. Limites e possibilidades da educação...

deficiente do espanhol como também de sua própria língua indígena. ${ }^{9}$ Uma dificuldade adicional para a EBI é a existência de oito dialetos no interior da língua quetchua. ${ }^{10}$ Será possível que os professores que falam melhor o quetchua que o espanhol possam ensinar corretamente o espanhol como uma segunda língua? Será surpreendente que o espanhol seja ensinado pelos professores onde a língua materna seja precisamente o espanhol como se vê numa Aliança Francesa ou em outros centros de ensino de inglês ou de alemão como segunda língua. " A realidade da EBI no Peru está longe desse ideal. Uma confissão sincera da senhorita Carmen Flores na comunidade de Sahuapuquio, em Puno, poderia ser útil aqui:

Meus colegas (e eu) nós ensinamos em espanhol mas nós não ensinamos o espanhol, porque nas diferentes instituições nas quais nos formamos nós não recebemos um curso sequer para aprender a ensinar o espanhol. Nossos professores também precisavam dessa aprendizagem. Hoje, uma boa parte de nós tem esse mesmo problema e as crianças também o têm". (Flores, 1999, p. 13-14)

Se avançamos um passo a mais na linha descendente chegamos até as crianças porque para elas um ensino deficiente ou francamente ruim do espanhol é lamentável e produz entre os pais uma recusa legítima cheia de graves

9 Para uma visão mais completa dos problemas que o ensino de quetchua tem, leiamos o seguinte texto de Carmen Rosa Flores:

"1. Falta de prática na leitura e na escrita; 2 . Material didático insuficiente nas escolas no campo; 3. Má aplicação da metodologia da EBI na sala de aula; 4. $O$ professor não tem domínio da língua quetchua; 5. Desconhecimento do conceito 'interculturalidade'; 6 . Diversidade dialetal do quetchua nos textos escritos; 7. Falta de um currículo diversificado; 8. Falta de formação suficiente para empreender a EBI; 9. Os esquemas de diretrizes tradicionais continuam ainda nas escolas do campo; 10 . Falta de um programa de orientação para os pais sobre a importância e os objetivos da EBI que possa neutralizar a oposição destes à EBI; 11. Falta de uma maior difusão da EBI; 12. As escolas no campo têm classes com diferentes níveis ou têm muitas salas para um único professor; 13. Falta de uma ideologia política da EBI; 14. A EBI deveria ser aplicada a partir de critérios lingǘsticos mais do que políticos". (Flores, 1999, p. 19-20)

10 Face a essa dificuldade Vicentina Huamanquispe sugere:

"É necessário empreender uma padronização de uma variedade supra-dialetal do quetchua $\mathrm{e}$ a elaboração de uma gramática para homogeneizar as diversas variantes a fim de definir um modelo para o uso da língua." (Huamanquispe, 1999, p. 20)

11 Nesses centros especializados, os alunos preferem os professores de origem estrangeira mesmo quando os professores nacionais possuem pleno domínio dessas línguas. 
MONTOYA ROJAS, R. Limites e possibilidades da educação...

consequiências para a EBI. Entre os pais o desejo de que seus filhos aprendam o espanhol para melhor se defenderem é unânime, enquanto suas opiniōes sobre a necessidade de seus filhos aprenderem a ler e a escrever em sua língua materna estão claramente divididas. ${ }^{12}$ Aqueles que preferem um ensino unicamente em espanhol possuem um argumento bastante forte: "se as crianças já conhecem sua língua materna, elas não têm necessidade da escola". Os argumentos da complexidade das línguas e de que não é suficiente falar uma língua para conhecê-la bem não têm força, apesar de seu grau de verdade, porque os pais, analfabetos ou semi-analfabetos, não têm a possibilidade de constatá-los.

Os pais têm a firme esperança de que seus filhos aprendam o espanhol e eles aceitam a possibilidade de uma EBI unicamente quando se lhes assegura que o ensino não será exclusivamente na língua indígena. Eles não têm mais a possibilidade de verificar que do ponto de vista pedagógico será melhor que as crianças comecem a ler e a escrever na sua língua materna. Isso explica sua vigilância para que os professores ensinem o espanhol e a atenção dos professores para demonstrar aos pais que eles estão trabalhando em espanhol com as crianças. Quando os pais se dão conta de que os professores bilínguies mal conhecem o espanhol, é o projeto EBI em si que corre um grande risco, porque eles preferem um professor que fale bem o espanhol mesmo se ele não conhece nada da cultura indígena. Portanto, uma das chaves para o sucesso da EBI é que ela leve em conta as reais aspirações dos pais.

12 Nos países de terceiro mundo, a educação é o último instrumento de mobilidade social que resta. Na Amazónia e nos Andes peruanos, todos os pais querem uma boa educação para os seus filhos. "Quando uma pessoa estranha chega numa comunidade nativa da Amazônia e apresenta suas credenciais informando o propósito de sua viagem, os dirigentes indígenas observam atentamente o papel, lêem-no calmamente, decifrando-lhe palavra por palavra, sflaba por sílaba. Em seguida pegam um caderno e uma caneta para escrever. Eles procuram fazê-lo bem calmamente e quando eles se dão conta de que para tentar escrever eles perdem o curso da conversação, então eles decidem apenas escutar. Para qualquer um que venha a descobrir a leitura, a palavra escrita tem um atrativo, uma magia toda especial. No silêncio dos gestos e das palavras que eles não se dizem podemos entender sua mensagem bem simples 'eu sei ler e escrever, olhe para mim, eu posso ser como vocês'. Na Amazônia e nos Andes de ontem e de hoje, aprender o espanhol é um meio para se defender, "um instrumento para abrir os olhos", e tornar-se igual aos outros. O mérito vem dos grupos étnicos da Amazônia, particularmente de seus dirigentes da primeira geração, de ter colocado a questão da educação recebida por suas crianças, e, sobretudo, qual educação elas mereciam. Não é suficiente que os professores cheguem com suas coroas invisíveis de luz e de saber. Se eles chegam do exterior, eles não conhecem as linguas indígenas, confundem a língua materna com a segunda língua, dão um tratamento prejudicial às crianças, abusam mesmo das meninas e culpam as crianças de seu péssimo resultado na escola. Esses pais reagiram à educação oficial e propuseram uma EBI. (Montoya, 1998, p. 47-48). 
Qual dos três espanhóis deve ser escolhido para o ensino da segunda língua? Se deixamos de lado o espanhol erudito - por ser inútil - e o espanhol andino pelas fortes influências que ele recebe do quetchua e do aymara, resta apenas o espanhol standard. Mas, nos Andes e na Amazônia, somente uma minoria dos professores estão em condições de oferecê-lo.

Pelo caminho percorrido até aqui na prática da educação bilíngüe nos diferentes países, uma das conclusões mais fácil de tirar é que a leitura e a escrita devem começar com a língua materna (L1) e continuar depois com a segunda língua (L2). Essa recomendação é seguida? Nós não dispomos ainda de uma resposta clara. Nós devemos estar bem atentos. Uma observação aguda de Carmen Flores é uma completa advertência.

Segundo a informação recolhida, o espanhol enquanto segunda língua é introduzido desde o começo. Do primeiro momento que a criança chega na escola, ela aprende a reconhecer as grafias do espanhol e aprende também a soletrar. As duas línguas são empregadas não importa em que momento. Quando o professor sofre a pressão dos pais, ele trabalha somente com o espanhol, e quando ele está sob a supervisão de um responsável da EBI, para dissimular, ele emprega a língua 2 apenas na expressão oral. Nessas circunstâncias ele não sabe que método seguir nem em que momento introduzir uma ou outra língua. Tanto os professores diplomados como os não-diplomados utilizam-se de palavras descontextualizadas. Eu nunca vi o uso de pares mínimos de palavras. As crianças não distinguem ' $e$ ' de ' $i$ ' nem ' 0 ' de ' $u$ '; em consequiência elas não distinguem as palavras nina e nena. Em quetchua nina quer dizer 'fogo' e nena é uma palavra espanhola para designar uma menina. Tentando aprender o espanhol, a criança diz a palavra 'nena' como se ela fosse a palavra 'nina' em quetchua. (Flores, 1999, p. 10-11)

\section{Política do Estado}

Em 1990, ousei falar da hipocrisia estrutural do Estado Peruano com relação à educação bilíngüe : apoio no discurso e desdém e esquecimento na 
MONTOYA ROJAS, R. Limites e possibilidades da educação...

prática. Foi o governo de Alan Garcia Pérez que criou a primeira Direção de educação bilínguie no interior do Ministério de Educação, 40 anos depois da primeira escola bilíngüe do ILE. Aparentemente o horizonte mudou, mas isso não passou de uma miragem. Seu primeiro diretor possuía apenas uma sala, uma secretária e algumas cadeiras. A verba prometida nunca chegou. Quando o presidente atual, o engenheiro Alberto Fujimori foi eleito em 1990, seu gosto pelas viagens ao interior do país e seu prazer de se ver vestido e fotografado com as vestes étnicas pareciam mostrar seu aparente interesse pelos grupos indígenas do Peru. Alguns analistas políticos estavam convencidos de que ele foi eleito com um voto étnico, porque o povo gentilmente o chamava "chinito" (pequeno chinês) devido à sua semelhança com alguns índios peruanos. A decepção foi bem grande. Quando o Ministério da Educação foi reestruturado, a Direção de Educação Bilíngüe foi eliminada. No segundo governo, 19952000, ele ordenou a criação de uma Unidade de Educação Bilíngüe, sem o cargo de uma direção. Esse passo atrás se explicaria pela pressão do Banco Mundial para que o Peru pudesse ter uma política de educação bilíngüe, seguindo, talvez, o exemplo do governo boliviano de Sanchez de Losada, como uma condição para financiar os projetos de desenvolvimento. $O$ Peru tem um certo número de especialistas altamente qualificados em EBI que infelizmente não trabalham no Peru por causa da falta de uma política nacional de envergadura na questão da educação para os povos indígenas, comparável à dos bolivianos e também à dos equatorianos. Parece que o governo peruano preferiu apelar para algumas ONGs, privatizando de certa forma a EBI, muito mais do que preparar a sua própria alternativa com um projeto nacional de mais fôlego. ${ }^{13}$

Trata-se de uma situação bastante delicada. As questões são numerosas e nós não temos as respostas ainda. Em 1997, quantas ONGs estavam em condição de responder a essas exigências? Quantas das ONGs foram criadas especialmente para esse trabalho? Será que elas têm pessoal qualificado para realizá-lo? Será possível formar professores bilíngües com alguns cursos de apenas duas semanas? Parece-me urgente fazer uma avaliação independente do trabalho dessas ONGs no terreno difícil e complexo da EBI. Será lamentável que uma alternativa rica e necessária para o país possa correr um risco tão grave.

13 A constituição peruana de 1993, aprovada pelo governo do Presidente Fujimori, diz em seu artigo 48: "O espanhol é a língua oficial, e são também oficiais o quetchua e o aymara nas regiōes onde elas predominam bem como as outras línguas indígenas". $O$ artigo 17: "O estado garante a educação bilíngüe e intercultural segundo as características de cada regiāo, preserva as diversas manifestaçōes culturais e lingüísticas do país e garante a integração". 
O aparelho burocrático do Ministério da Educação é complexo, contraditório e bem pouco homogêneo. Basta que um funcionário anti-indígena esteja na direção para que ele tome decisões contra a EBI mesmo se ele repete de cor um discurso formal a favor. Os textos seguintes são exemplares:

Nas salas de aula da professora participam quatro crianças no primeiro nível, quatro no segundo e três no terceiro. De modo geral dois professores trabalham em cada escola rural. As autoridades educacionais de Puno decidiram oferecer a EBI apenas nas escolas que têm um número reduzido de alunos. Em contraposição, nas escolas rurais com mais alunos e que possuem um quadro completo de professores apenas a educação oficial é ofertada. Essa decisão é absurda porque a maioria dos alunos dessas escolas falam o quetchua (Huamanquispe, 1999, p. 10).

As escolas com o programa EBI encontram-se nos locais mais distantes, longínquos e inóspitos de nossa jurisdição de Puno. A maioria dos professores encarregados desse programa têm apenas um contrato de trabalho temporário e outros têm uma nomeação provisória. Outros ainda não têm diploma e seguem seus estudos à distância; alguns esperam melhorar sua situação e outros ainda trabalham sob pressão das autoridades (Flores, 1999, p.10).

O que se deve pensar dos funcionários do Estado que nomeiam e designam um professor aymara para uma escola em que todos os alunos falam quetchua ou que enviam um professor de educação física para dirigir uma escola de EBI?

O contraste entre as experiências de educação bilíngüe no Peru e na Bolívia merece um parágrafo especial. O presidente neo-liberal Sanchez de Losada é o responsável pelo projeto nacional de educação bilíngüe intercultural de grande envergadura nacional na América do Sul. Infelizmente uma oposição radical dos sindicatos dos professores limita as possibilidades desse projeto. ${ }^{14}$ Uma quantidade dos projetos ditos "pilotos" no Peru não é suficiente para se ter uma política para o conjunto dos grupos étnicos do país. Quadros alta-

14 Entre nós, no Peru, a oposição radical dos professores foi decisiva para o fracasso da reforma educacional do general Velasco Alvarado em 1971. Os salários muito baixos, as condiçōes de trabalho muito duras e, principalmente, sua exclusão no momento de preparar a reforma explicam esse comportamento. 
MONTOYA ROJAS, R. Limites e possibilidades da educação...

mente qualificados e centenas de professores com uma experiência adquirida importante no Peru não são devidamente explorados. Eles são forçados a deixar o país ou trabalhar em condições extremamente difíceis.

\section{Problemas com a interculturalidade}

Na prática cotidiana da biculturalidade, as professoras e professores têm acesso a diversos fragmentos das duas culturas e em alguns locais até de três culturas e três línguas. Entretanto, esse acesso não é suficiente para compreender-se bem os problemas que essa multiculturalidade produz num país tão contraditório quanto o Peru e nos programas específicos de educação bilíngüe. $\mathrm{Da}$ mesma forma que aquele que fala somente a sua língua não está qualificado para ensiná-la, aquele que vive unicamente no interior da sua cultura, sem fazer um esforço para estudá-la, não está em condições de ensiná-la para as crianças de uma escola bilíngüe. A definição de uma educação intercultural, que é principalmente uma afirmação de intenções, exprime uma certa vontade de apresentar as duas culturas em igualdade de condições e de facilitar seu diálogo. Contudo, da intenção à realidade ainda há uma distância muito grande. Uma pergunta aqui é decisiva: que formação os professores recebem em antropologia e em interculturalidade? Até que ponto não se trata de uma ausência dissimulada por belas palavras? Nós temos necessidade de respostas em cada um dos casos. Aquela do projeto de Iquitos aparece como inteiramente especial depois de cinco anos de formação em antropologia, linguiística e pedagogia. Ao contrário, no caso dos cursos pequenos de uma ou duas semanas por ano junto ao Ministério da Educação ou às ONGs, não podemos esperar bons resultados.

Para que a idéia de um diálogo de culturas em relativa igualdade de condições seja possível, é necessário apresentar os traços mais importantes das duas culturas de forma ordenada, para mostrar especialmente suas semelhanças, suas diferenças, os pontos de diálogo e o predomínio de uma sobre a outra. Cada cultura tem suas respostas para os problemas universais ou quase universais, seus sistemas classificatórios, seus princípios e pilares. Preparar os conteúdos quetchua e aymara para os cursos da escola primária dentro da EBI de Puno foi um longo e difícil trabalho para cada um dos grupos responsáveis pelas ciências naturais, ciências humanas e matemática. Uma vez estabelecido um registro dos principais elementos das duas culturas, resta ainda explicar o complexo mecanismo de dominação entre elas e, principalmente, mostrar aos 
MONTOYA ROJAS, R. Limites e possibilidades da educação...

professores bem como aos alunos as propostas para reduzir e eliminar essa dominação.

\section{Os professores: condições de existência, de trabalho e os graves problemas em sua formação}

Um professor me contou, em 1997, numa escola perto do rio Corrientes (Amazônia peruana): "Eu não tenho aquilo que é necessário para dar meus cursos normalmente. Enquanto estou com meus alunos numa sala de aula, os alunos de outra sala não têm nada para fazer"(Montoya, 1998, p. 49, nota 29).

Nos altos planaltos de Puno, perto da fronteira com a Bolívia, uma professora disse à Vicentina Huamanquispe: "Senhorita, aqui as crianças não têm nenhum material. Eu tenho que fornecer todo o material e até comprar os lápis. Os pais não dão apoio. Eu tenho que comprar até os cadernos. Os pais enviam suas crianças com um caderninho para o ano todo". (Huamanquispe, 1999, p. 7)

A pobreza é visível e dramática em todas as escolas bilíngües dos Andes e da Amazônia e também em todas as casas dos professores e professoras. Como isso poderia ser diferente se seu salário mensal é mais ou menos cem dólares. Esse dinheiro não é suficiente para se viver com um mínimo de decência, isto é, alimentar-se convenientemente, vestir-se com sobriedade, ter uma pequena biblioteca, comprar jornal e algumas revistas para estar atualizado na vida profissional. Ver as escolas bilíngües sem bibliotecas nem material didático, as crianças mal alimentadas, os professores mal vestidos e com o rosto cheio de preocupações e angústia produz num colega visitante uma dor e um sentimento de impotência e de indignação. ${ }^{15}{ }^{16}$ Nenhuma criança, nenhum professor, nenhuma escola merece esse tratamento desumano. Mas a realidade é assim, e se deteriora: Em 1970 a situação era menos dramática. ${ }^{17}$

15 Carmen Rosa Flores aluna do Mestrado de Lingülstica Andina e Educação em Puno, perguntou à professora Higina Ticona da comunidade de Muruhuanza: "Quais são os problemas para o ensino de língua materna aqui?". "Falta alimentar as crianças" foi sua resposta. (Flores, 1999, p. 30-31)

16 Contudo, nessas escolas tão bonitas encontram-se apenas alguns quadros, algumas cadeiras e pastas vazias. Não se vê nenhuma biblioteca nem, material didático. Uma mesma sala de aula serve para alunos de três níveis diferentes. (Montoya, 1998, p. 49)

$17 \mathrm{Em} 1970$ os salários estavam proporcionalmente mais elevados e os professores 
MONTOYA ROJAS, R. Limites e possibilidades da educação...

Além disso, os professores sofreram outro abandono, que se pode descrever com a palavra órfão, que, nas tradições quetchua e aymara, tem uma importância enorme após a conquista espanhola de 1532:

O professor rural tem muitos limites e insuficiências no desenvolvimento de seu trabalho educacional porque ele não teve uma boa formação e, pior, porque ele trabalha nas aldeias muito distantes. Mesmo os especialistas em educação bilíngüe não o visitam; ele está abandonado como um órfão; ele não tem ninguém para orientá-lo. (Flores, 1999, p. 1)

Considerando-se a complexidade de uma educação em duas línguas e em duas culturas, e as grandes distâncias que os professores têm que percorrer para chegar a suas escolas, eles deveriam receber uma formação mais especializada, ter melhores salários e dispor de vantagens em suas carreiras profissionais; contudo, na realidade, ocorre exatamente o contrário. Em última instância, a responsabilidade dessa verdadeira tragédia cabe aos Presidentes da República que depois de 1968 agiram de forma a que a situação educacional ficasse cada vez pior.

Aos problemas já assinalados eu gostaria de acrescentar um outro : o ressentimento dos professores, com características biológicas indígenas, contra Lima e os representantes de Lima, a Espanha e o espanhol:

Com relação à questão "qual é a sua opinião sobre a educação bilíngüe e intercultural?", o professor da escola da comunidade de Sutuca Urinsaya respondeu: "eu acho que ela é de importância vital. O espanhol não é originário do Peru, o quetchua é nossa língua e nós devemos falá-la e difundi-la em todas as escolas rurais e também urbanas e porque não em nível nacional" (Huamanquispe, 1999, p. 17).

das escolas não precisavam de um segundo emprego como hoje. Eles tinham o reconhecimento dos pais e das comunidades. 
Se depois de cinco séculos o espanhol é ainda visto como uma língua estrangeira e imposta, então as feridas produzidas pelo cataclisma europeu de 1532 - "o mundo virou do avesso", escreveu Guam॰n Poma de Ayala, o cronista e etnógrafo índio, - ainda continuam abertas. Outro relato confirma essa triste conclusão : "O professor que pertence ao programa de educação bilíngüe e intercultural enfrenta contextos desfavoráveis. Pelo fato de ter sido formado por esse programa ele é considerado inferior por seus colegas professores cuja língua materna é o espanhol" (Flores, 1999, p. 112-113). Os professores bilíngües são também, como seus alunos, vítimas do racismo. Seu ressentimento é apenas uma reação contra essa discriminação.

A formação de educadores, tão ruim e deficiente, é também um resultado da crise lamentável da educação pública, primária, secundária e universitária. Resta, ainda, um último problema: a ausência de vocação daqueles que se tornam professores ou professoras unicamente porque têm necessidade de um emprego qualquer, mesmo se se tratar de um emprego exclusivamente temporário : "Na maioria dos casos, os professores da EBI não têm a vocação para serem educadores. Essa profissão é apenas um refúgio. Eles não têm nenhuma vontade de melhorar sua situação e dizem que se o governo pudesse ajudá-los, eles mudariam de trabalho."(Flores, 1999, p. 14)

\section{Perspectivas}

O conteúdo deste trabalho mostra, infelizmente, o momento bastante difícil da EBI no Peru. É indispensável ter o espírito crítico para observar a realidade e para não descambar para um otimismo exagerado ou irreal. Eu quero lembrar aqui que estou persuadido e convencido da necessidade de uma EBI nos países que têm um importante componente multicultural e que eu admiro o sacrifício de centenas de professoras e professores com uma vocação tão clara, bem como os esforços dos lingüistas e pedagogos para firmar essa alternativa educacional. Sem um apoio governamental decisivo, sem um engajamento dos próprios Presidentes da República, a EBI é apenas uma frágil proposta. Uma EBI de péssima qualidade, que não responde às expectativas dos pais, pode conduzir à decepção. Seria verdadeiramente triste que os pais a recusassem com o forte argumento da má qualidade. Os povos indígenas merecem mais.

(Tradução: Lígia Negri/UFPR) 


\section{REFERÊNCIAS}

CALSIN VILCA, D. P. Una muestra de aplicación de la lengua vernácula en la Educación Bilingüe Intercultural. Puno, 1999. Maestría (Lingüística Andina y Educación) Universidad Nacional del Altiplano. Mimeog.

FLORES FLORES, C. R. Problemas y perspectivas de los docentes en la enseñanza del castellano (L2) de las escuelas con programa de EBI [Educación Bilingüe Intercultural] de la zona quetchua Puno. Puno, 1999. Maestría (Lingüística Andina y Educación) Universidad Nacional del Altiplano. Mimeog.

HUAMANQUISPE, S. V. Problemas y perspectivas en la enseñanza de la lengua materna (quetchua) en la Educación Bilingüe Intercultural. Puno 1999. Maestría (Lingüística Andina y Educación) - Universidad Nacional del Altiplano. Mimeog.

INSTITUTO LINGÜÍSTICO DE VERANO. Recordando cuarenta años 1946-1986. Lima: ILV, 1986.

INSTITUTO LINGÜISTICO DE VERANO. Bibliografia 1946-1986. Lima: ILV, 1987.

INSTITUTO LINGÜISTICO DE VERANO. Educación bilingüe: una experiencia en la Amazonia peruana. Lima: I. P. Pastor, 1987.

LOPEZ, L. E. Pesquizas en lingüística Andina. Puno: Concitec, Universidad Nacional del Altiplano, Cooperación Alemana GTZ, 1988.

MERCIER, J.-M. Nosotros los Napuruna ñNapurunapa rimay - Mitos e historia. Iquitos: CETA, 1979. Edição bilíngüe.

MONTOYA ROJAS, R. Capitalismo y no capitalismo en el Peru. Lima: Mosca Azul, 1980.

. La cultura quetchua hoy. Lima: Hueso Homero, 1987.

.Por una educación bilingüe en el Peru: ensayos sobre cultura y socialismo. Lima: Mosca Azul, CEPES, 1990.

Al borde del naufragio: democracia, violencia y problema étnico en el Peru. Madrid: Talasa /Lima: SUR, Casa de Estudios del Socialismo, 1992.

. Multiculturalidad y política: derechos indígenas, ciudadanos y humanos. Lima: SUR, Casa de Estudios del Socialismo, APRODH, 1998. 
. El tiempo del descanso (novela). Lima: SUR, Casa de Estudios del Socialismo. Traduzida para o português: $O$ tempo do descanso (romance). Tradução: Urpi Muriarte. São Paulo: Marco Zero, 1998.

; MONTOYA, L.; MONTOYA, E. Urqukunapa yawarnin - la sangre de los cerros. Antología de la poesía quetchua que se canta en el Peru (con 333 canciones en edición bilingüe y 170 partituras de música). 2. ed. Lima: Universidad, Federico Villarreal, 1998. 5 volumes.

WICLIFFE BIBLE TRANSLATORS. Who brought the word? Santa Ana, CA: XX, 1963. 